\title{
Mopo'a Huta on Peasant Community: A Ritual for Harmony with Nature in Molamahu Village of Gorontalo Regency - Indonesia
}

Momy A. Hunowu ${ }^{1}$, Hatim B. Pakuna ${ }^{2}$, Lahaji ${ }^{3}$, Muhammad Obie ${ }^{1 *}$

${ }^{1}$ Department of Sociology, State Islamic University of Sultan Amai Gorontalo, Indonesia

${ }^{2}$ Department of Philosophy, State Islamic University of Sultan Amai Gorontalo, Indonesia

${ }^{3}$ Faculty of Sharia, State Islamic University of Sultan Amai Gorontalo, Indonesia

*Corresponding Author Email: obiclimber@gmail.com

\begin{abstract}
This study analyzed the concepts of nature and its inhabitants, as well as the actions of peasants creating harmony with nature. This study used a qualitative approach with ethnographic methods. The data collected was mostly primary data obtained through in-depth interviews and passive participation observation. To support primary data, the researchers also collected secondary data, such as publications and previous research reports. In analyzing the data, the researchers made interview transcripts, data reduction, analysis, data interpretation, and triangulation. The results found that the peasant community believed in supernatural beings as part of the forces of nature. It can do anything depending on the relationships built by the community. Mopo'a Huta ritual is the human action to create harmony with nature. The ritual begins with a procession of dance accompanied by drum beats for several nights. On the last day, offerings are prepared to entertain supernatural beings. With this banquet, the peasant community hopes that spirits no longer disturb them so that peace and prosperity can be created.
\end{abstract}

Keywords : Mopo’a Huta, Peasant Community, Ritual, Tradition, Harmony with Nature

\section{INTRODUCTION}

Rural communities, in general, have a reciprocal relationship that is in harmony with nature. This relationship is manifested in the form of interaction, both directly and spiritually. In their ongoing interactions, rural communities gain experience and knowledge that gives clues about what they can expect from nature. Both naturally and as a result of their actions (consequences), and about what can be done (mandate) and what should not be done, and the spiritual beliefs of rural communities treat nature, that nature is related to the unseen (Keraf, 2002). This treatment is carried out in the form of traditional ceremonies. Traditional ceremonies are included as one of the universal cultural elements; their existence is found in almost all cultures of ethnic groups in Indonesia. Traditional ceremonies are official behaviors that are standardized for events that are not aimed at daily technical activities, but are related to beliefs that there are forces beyond the capabilities of humans or supernatural forces, such as the spirits of village founding ancestors, ancestral spirits that are considered to provide protection to offspring still, etcetera (Budhisantoso, 1989). The implementation of traditional ceremonies is intended to maintain harmony between living things, which, if not carried out, will cause disaster.

In this perspective, the belief that is understood and lived by indigenous peoples is a way of life, to organize the entire human life in a harmonious relationship with fellow humans and nature. With 
such appreciation, indigenous people always want to find and build harmony between humans, nature, society, and the unseen world, based on the understanding and belief that the spiritual is integrated with the material. Harmony and balance are, at the same time, understood as the most important principles or values in the cosmic order (Keraf, 2002).

In this connection, morality is the inherent demand of every indigenous community. This morality concerns human behavior with not only each other but also humans with themselves and also with nature. There is a religious-moral conviction, that wrong attitudes, and behavior, which are crooked, that damage relations with others and nature, will wreak havoc, both for oneself understood that all-natural disasters - floods, drought, pests, crop failures, lack of results catch in the sea, everything is considered to originate from the error of the inner attitude and human behavior, both towards fellow humans and nature. There needs to be a reconciliation in the form of religious ceremonies, traditional ceremonies, by bringing victims both to fellow victims who are injured and to nature that has been damaged. There needs to be a recovery of broken relations. In other words, moral behavior, both towards others and towards nature, is part of the way of life, from customs, from the ethics of the indigenous people (Keraf, 2002).

Traditional wisdom practiced by society contains values, norms, beliefs, and special rules. These various forms cause the function of local wisdom to be diverse too. These functions include: 1) Local wisdom serves to conserve natural resources; 2) Local wisdom functions to develop human resources; 3) Functioning as the development of culture and science; 4) Functioning as advice, beliefs, literature, and taboos (Aulia, 2010).
Substantially, local wisdom is the values that apply in a community, the values that are believed to be accurate, and become a reference in the daily behavior of the local community. Therefore, it is reasonable if Geertz states that local wisdom is an entity that determines the human dignity in his community (Geertz, 1960). It means that local wisdom, which contains elements of creative intelligence and local knowledge from the elite and its people, is crucial in the development of the civilization of its people.

The community expresses various traditional wisdom in the form of rituals (religious ceremonies). Rituals, as explained by Turner (1982), are certain behaviors that are formal, carried out in a certain period, not as routines that are technical, but refer to actions based on religious beliefs about power or mystical power (Sambas, 2015). Furthermore, according to Turner (1982), ritual has several roles including 1) rites can eliminate conflicts; 2) rites can overcome divisions and build community solidarity; 3) rites unite two conflicting principles; 4) with rites, people get new strength and motivation to live in everyday society (Sambas, 2015).

The function of rituals (religious ceremonies) is to seek safety, peace, and preservation of life. Humans always try to resist distress and maintain life balance by carrying out religious ceremonies that create human efforts to save themselves. Religious ceremonies carried out by religious adherents have a social function to integrate community solidarity (Koentjaraningrat, 1985).

Religious ceremonies are often performed when in a state of danger or crisis so that in carrying out them, humans will get peace of mind. Therefore, the function of ritual is to protect the individual from doubt and danger by anticipating and overcoming it symbolically, so that it soothes the anxiety of the 
dangerous situation to people without a handle and avoids the damaging effects it has (Odea, 1996).

Previous studies explain how the community performs rituals as an effort to maintain harmony among the inhabitants of nature. Suryani's research on alms has similarities with this research. Tayub has been performed in this ritual ceremony for a long time according to the tradition that is inherited by the ancestors. According to the community leaders and head of the village, Tayub is performed in Alms Earth in order to avoid dangerous disasters. Another reason is that Tayub is one of the favorite dances of the spirits in that village (Suryani, 2014).

In contrast to the earth alms carried out after harvesting by the Javanese people, as a form of gratitude for the abundance of sustenance, the mopo'a huta ritual for the people of Gorontalo was carried out during the famine season. The traditional mopo'a huta ritual is considered as a form of reconciliation so that human harmony with nature occurs. Etymologically mopo'a means to feed, huta means land. So, in terms of mopo'a huta is a ceremony to feed the land (nature) (Ahaya, 2019). This ceremony is held several consecutive nights by beating drums that accompany the dances of certain people to possess. This tradition is similar to alms in the Pati community of Central Java. Alms for the people of Pati is a form of gratitude to God Almighty, for the abundant harvest. In alms accompanied by traditional music, namely Karawitan art (Suryani, 2014).

The highlight of the mopo'a huta ritual is in the morning, where the community prepares offerings, with a particular food menu from certain ingredients derived from the natural surroundings. Held around the dance arena near the river and presented to spirits. The mopo'a huta ritual is believed to be able to make abundant harvests, free from prolonged drought and famine, crop failure, and breeding livestock, and all citizens avoid disease and successive deaths. This research answers research questions, how is the conception of nature and its inhabitants according to the beliefs of the peasant community, and how the peasant community act in creating harmony with nature.

\section{METHODS AND MATERIAL}

This research was conducted by a qualitative approach with a case study and ethnography method. The case study method intended to make the case study more focused (Surakhmad, 1982). The case study was the harmony between nature and human beings. Meanwhile, ethnographic methods were employed to understand the peasant view on the conduction of mopo'a huta ritual (Spradley, 2007). The collected data was mostly primary data obtained through in-depth interviews and passive participation observation (Sugiyono, 2009; Moleong, 2007). Informants, as the source of qualitative data, were selected through snowball techniques. The researchers first interviewed some key actors (ritual leader and older people), then asked them to mention other actors whom they perceived to have some understanding of the research problems. Thus, the number of informants was snowballing (Sugiyono, 2009). To support the qualitative data, the researchers also collected secondary data, namely publication and previous research reports on the history of peasant communities related to natural resource management. The researchers then analyzed the data qualitatively. In analyzing the data, the researchers made transcripts of interviews, data reduction, analysis, data interpretation, and triangulation. From the results of the analysis of the data, the researchers then conclude. 


\section{RESULTS AND DISCUSSION}

\section{The Concept of Nature and Its Inhabitants}

The peasant community considers that nature is the source of life, so nature must be protected and respected. Nature is something sacred, so that spirituality is the highest awareness, at the same time animating and coloring the whole relation of all creation in the universe. It includes human relations with humans, humans with nature, and humans with the unseen. This view is formed from the results of a prolonged interaction between the community and nature. From here, people conceptualize their relationship with nature and form values that are believed to be accurate and serve as a reference in daily behavior. This view is in line with Obie's research (2015) on the Bajo tribe community on the coast of Tomini bay, where Bajo people conceptualize themselves as part of the coastal and marine natural resources where they reside.

The concept of nature, according to peasants in Molamahu village of Gorontalo Regency, namely nature is the source of life, nature is the gift of God, and humans and spirits inhabit nature. The peasant community firmly believes that their lives depend on nature. That is why they have awareness and belief that nature must be preserved. The first concept formed is nature as a source of life, that from nature, they get prosperity. It builds its awareness that nature must be maintained so that it continues to give life. That belief is increasing that when nature wrath, a hint of disaster for humanity. It is very reasonable; the farming community in their daily lives is very dependent on nature. It is nature that provides what is needed for survival. They cultivate nature with simple equipment. This condition continues to develop into more modern. They reap the results of their efforts to meet the needs of everyday life.
While waiting for the harvest, some peasants go to the forest to look for rattan and make wooden blocks for sale. The forest for the peasant community is like a supermarket that can provide many things to meet the needs. They do not exploit the forest; they only take crops that are already harvested, both rattan and cutting down wood trees that can be used as blocks with a length of four meters for sale.

Nature is also used as a restful residence. The peasant community has the concept of nature with two functions, namely as a place to obtain a comfortable life and place of residence. When nature no longer gives life and is no longer appealing, then something is wrong with humans. To ensure that nature is well preserved, the peasant community believes that the key is in the spring. Two springs formed into rivers save natural wealth, which is very astonishing; the wealth is in the form of chunks of gold. The presence of a sacred tomb mystically preserves the source of natural wealth. People believe that gold is tied to a chain, and the end of the chain is tied to the toe of Poliduhelo (holy figure, the first human in the village). That is why the chunk of gold cannot be taken. People who feel strange about natural phenomena immediately make a pilgrimage to the sacred tomb. All the advice delivered by pilgrims possessed by them becomes an important message that must be implemented. When this is not done, nature will be angry. The wrath of nature presents not only drought but also floodwaters. If two of these springs coincide, floods will destroy all life downstream. The last flood that hit the peasant community was a flash flood in the 1970s, although the death toll did not reach ten people, this flood was recorded in the memory of the peasant community as a flood that could make the region like the sea.

The second concept formed is that nature has existed since the days of their ancestors. Nature is a gift from God that is given to the Caliph to be managed based 
on the values of local wisdom. Structuring the village is done not only physically but also spiritually. They are organizing the village physically, like building village facilities and infrastructure, especially those related to meeting the basic needs of the community. While spiritual development is related to managing human relations with the inhabitants of nature, this relation is related to the spiritual and psychological aspects, namely the vertical relationship with the ruler of nature, serenity, and comfort. The peasant community gained knowledge about how to build relationships with nature, where they lived for generations. Obie et al. (2020) state that to preserve the environment, the peasant community implements various restrictions.

The peasant community gained this knowledge through a long experience of living alongside nature. That knowledge continues to be accumulated and expressed in the form of traditions that become local identities. It is what they maintain so that there will be continuity of life in the universe. They have ideas on how to keep nature, giving many things for them, where the ideas are expressed in the form of rituals. The implementation of the ritual requires a week or more, which in its implementation requires cultural objects which become the ritual media. With this ritual, it can be seen that the peasant people have a high spirituality. This spirituality becomes the capital to maintain a harmonious relationship with nature. There is a belief that famine, prolonged drought, crop failure due to pests, livestock dying suddenly, strange diseases (mystical) attacking residents, and the death of consecutive family members have a strong relationship with the supernatural.

From the above statement, it can be seen that the natural conditions that are not friendly, strange, or mystical diseases and successive calamities, people believe, as a sign that something is wrong. It indicates there is a relationship that is less harmonious between the inhabitants of nature so that other creatures try to disrupt the lives of humanity. That is what forms the concept of managing the village.

Based on observations, during September and October 2019, there were successive calamities in two adjacent hamlets. There were ten deaths from families who still had kinship ties. Some people, especially the elderly, believe that this is an incredible event. There is something that is starting to be ignored by the community, namely the ancestral inheritance, which is a problem solver under these conditions. This belief then gave birth to the idea, so that humans are not disturbed by other creatures, then humans must do something as a form of reconciliation with the ruler of nature. The peasant community embodies this reconciliation in the form of rituals by holding a traditional mopo'a huta ritual.

The third concept is that humans and spirits inhabit nature. Spirits have extraordinary strength. They can disturb humans not only spiritually but also physically-many terrible stories about experiences of spirits. Forming beliefs, there is a natural ruler; therefore, humans must behave well with fellow natural inhabitants in order to avoid things that are not desirable. Relevant to Armstrong's opinion that humans are spiritual beings. Humans worshiped the gods as soon as they realized themselves as humans; they created religions at the same time they created art. They believe that behind the universe, there is a supernatural power that governs and created them. This power is not visible, but they believe in its existence (Armstrong, 2014).

\section{The Action of Peasant Community in Creating Harmony with Nature}

The peasant community has a complete concept of nature, its inhabitants, and the forces within it. The forces of the inhabitants of nature are believed to be a 
destructive threat on one side but can create wellbeing and peace if there are harmonious relations on the other side. This perception gives birth to activities or actions aimed at controlling the destructive forces of nature. Under these conditions, the peasant community will do something, as a form of culture that starts from ideas, then manifests in the form of activities and rituals and can be seen in the form of artifacts. Humans can take action as a form of positive reciprocity in the environment (nature) where humans are looking for a living (Arinda, 2014).

Fear of disaster, fear of crop failure, the number of strange and mystical diseases essentially characterize religious people or have divine potential. Having fear as a sign of god and having the potential to worship God with fear, the peasant community seeks protection in the form of worship. Carrying out the mopo'a huta ritual is a form of worship as an expression of recognition of God's omnipotence. Beliefs about the threat of powerlessness of peasants to the supernatural forces of nature require that they take actions that can control the forces of nature. The mopo'a huta ritual is one of the expressions of religious diversity that creates harmony among the inhabitants of the universe.

One of the great traditions carried out by the peasant community when they obtain a fortune at harvest is sharing. In the sustenance, there are already parts of the village head, neighbors, and friends who are harvested from certain places. Here there is a tradition of giving five corn cobs to a neighbor before corn is harvested. The maize is taken from the five points of the corn crop area, namely four from each corner of the land, and one point in the middle of the land. The message carried by this tradition is that there is a balance in human life by always remembering the neighbors around them. The corn will be distributed to their neighbors. This tradition is believed to avoid wild boar pests in the next planting season; besides, if it is not distributed to trusted neighbors, they will be affected by the disease (Fadhilah, 2013).

The tradition of sharing is not only with fellow humans but also with fellow creatures of God. A simple example, someone who wants to eat in the open, spontaneously, he will throw a handful of food while saying, tima'o tayadi mongoli, dilame po'o langgu (this is part of you, do not disturb us). Sharing with spirits on a large scale is done during the mopo'a huta ritual. In this ritual, the peasant community provides offerings in the form of twenty-five of food packages made from native chicken, eggs, cork fish, wood bananas, sago, and other ingredients. All materials must come from the village, and cooked without seasoning. The action to carry out the mopo'a huta ritual is a collective decision between a ritual leader, traditional leaders, and village heads. The village head immediately ordered his subordinates at the hamlet level to raise funds. It is collective, for all nature and its contents.

There are two fundamental elements in each frame of local belief, namely locality and spirituality in which both influences, synergize and integrate with one another (Ismail, 2012). In the context of the mopo'a huta ritual, the locality aspect is the presence of the Tiluti and Pongawaa springs, along with the sacred tombs that synergize and integrate with the spirit expressed in the mopo'a huta ritual. Without the presence of rivers and sacred tombs, it seems that this ritual will lose its meaning and sacredness. Precisely the view of Keraf (2002), nature for peasant community is something sacred, so that spirituality is the highest awareness, at the same time animating and coloring the whole relationship of all creations in the universe, including the relationship between humans and humans, humans and nature, and humans with supernatural beings or holy beings. 
The mopo'a huta ritual is a form of awareness to arrange harmonious relations, both with fellow local communities, with nature and with spirits. The implementation of the mopo'a huta ritual is unique to the same ritual carried out in other villages in the Gorontalo regency. Local beliefs develop in localities with different backgrounds in life, traditions, customs, and culture, so it can be ascertained that each of these local beliefs shows different characteristics that differ from one another. In other words, the trust that is in one region will be different from the local trust in another region (Ismail, 2012). In practice, there are three main elements in the mopo'a huta ritual, namely the drumbeat, dancers, and offerings to sentient beings. For details, the stages of implementation can be described as follows;

1) The mopo'a huta ritual practiced by the peasant community begins with the pilgrimage to the sacred tomb of Poliduhelo. Poliduhelo's tomb is located right on the edge of a river that originates from Pongawaa and Tiluti. The two rivers meet and flow towards Limboto lake. Although on the banks of the river, this grave has never been touched by flooding. This phenomenon is increasingly adding to the confidence of citizens of the sacred residents of the grave. One day, a tree near a fallen tomb and covered the grave, miraculously, not long ago, the tree stood up straight again. Another story is when the sacred tombs were concreted (installed in tiles) by residents who claimed to be descended from Poliduhelo, before long the concrete collapsed dragged by river water. There was also someone who sank his tombstone into a river. Sometime later, the tombstone had returned to the sacred tomb. Residents who witnessed this phenomenon for the sake of that phenomenon were amazed and increasingly believed in the safety of Poliduhelo.

The people's perception of the tomb is strongly influenced by the religious style which is very
Sufistic and their belief that is visiting and praying for people who are close to God, God will bless their lives. They believe that such religious behavior does not contradict the Shari'a because they believe that all the prayers of Allah grant it, not the deceased. Visiting the tomb of a king or guardian will bring a positive influence on one's spirituality that all humans will return to God (Rusli, 2016).

Based on this understanding, Poliduhelo's tomb has become a medium and source of inspiration for the peasant community to hold a mopo'a huta ritual. For the pohile pohutu (ask permission to the sacred tomb to carry out mopua huta) procession, stages are carried out to call the spirit. Upstream, there are two river intersections, the river from the Pongawaa spring and the Tiluti river. It was there that the ritual leader stood to call for spirits. After the decision was made that the ritual should be carried out, the residents who had been waiting for certainty for the implementation of the dance ritual voluntarily prepared everything from the venue, the required objects to the licensing.

2) The second stage is to perform a dance with drum accompaniment. If the pilgrimage stage is carried out in the middle of the jungle, about seven kilometers from the village, then the implementation of the dance and drum is carried out in the village near the river flow. The dance is performed every night. The speed or duration of the ritual depends on the conduct of residents who are each night collected by the organizer.

"Usually, the implementation of dance takes place for three days, seven days, or a month. The duration of implementation is due to waiting for gifts from residents, as material to be provided for 
offerings. So, when the dance activity takes place, residents arrive and hand over chickens, cork fish, rice, money, materials that are collected. If within three days it is complete, the peak will be held, namely providing offerings" (Hasan, 2019).

In the dance procession, several moments attracted people's interest to watch. The dancers put on the red headband attribute worn by all dancers, and they come into the dance arena while singing wumbungo (Chanting when possessed by spirits). When entering the arena, where the drum beats with a certain rhythm, the dancers start convulsions, a sign of demon possession. They took turns dancing irregularly, up and down the drum.

3) At the peak of the dance and drum, there are twenty-five food packages held. Offerings are presented in the arena near the river and placed on tonggolo'opo (where the offerings are placed, made of woven bamboo with bamboo poles plus palm leaves) and dunayahe (a place of offerings of cigarettes and embers that are usually placed in the middle of the garden). At that time the ritual leader called out to the spirits to taste the offerings available. The sign that the spirits arrive when a partridge tied to the pole of tonggolo'opo flapped its wings and crowed, the atmosphere became silent, the wind seemed not to blow, the hairs on the neck stood up, felt chills that were the time when the summoned devils came. They tasted the dish without a reduced one. It is the peak of the sacredness of the mopo'a huta ritual. When the ritual leader invited the guests of the universe to attend a party with humans in the hope that harmony would occur between these different creatures, the sign that spirits have eaten food is that it has no taste, like coconut dregs. That is a sign that spirits have eaten the essence. After that, the dangling tonggolo'opo is pulled, along with all the yellow leaf attributes washed into the river. At this time also, all residents are prayed one by one by the ritual leader by rubbing certain body parts with river water to be free from all distress. The last stage is reading the blessings of the prophet and eating together.

\section{CONCLUSION}

The mopo'a huta ritual is still intact in the memory of peasant community. This community has the concept of supernatural beings as part of the forces of nature. This concept is not only embedded into a belief but also expressed in the form of actions (rituals). A mopo'a huta ritual is a form of friendship between humans and supernatural beings. As well as one of the community's actions to organize the village and create a prosperous community life physically and spiritually. It is relevant to the function of rituals as an effort to seek safety, peace, and preservation of life. Humans always try to resist distress and maintain life balance by carrying out rituals that create human efforts to save themselves.

The practice of mopo'a huta ritual is a way of life, intending to organize all human life in harmonious relations with fellow humans and nature. With such appreciation, the community always wants to find and build harmony between humans, nature, society, and the unseen world, based on the understanding and belief that the spiritual is integrated with the material. These harmony and balance are understood as the essential principle or value in the cosmic order.

\section{REFERENCES}

[1]. Ahaya, K. (2019). Personal Communication.

[2]. Arinda, R. I. Y. (2014). Sedekah Bumi (Nyandran) Sebagai Konvensi Tradisi Jawa dan 
Islam Masyarakat Straturejo Bojonegoro. El Harakah, 16(1), 100-110. http://dx.doi.org/10.18860/el.v16i1.2771

[3]. Armstrong, K. (2014). Sejarah Tuhan Kisah 4.000 Tahun Pencarian Tuhan dalam Agamaagama Manusia, translated from. A History of God: The 4,000 Year Quest of Judaism, Kristianity and Islam. Bandung: Mizan Pustaka

[4]. Aulia, T. O. S. (2010). Kearifan lokal dalam pengelolaan sumberdaya air di Kampung Kuta (Desa Karangpaningal, Kecamatan Tambaksari, Kabupaten Ciamis, Jawa Barat). Bogor: Institut Pertanian Bogor

[5]. Budhisantoso, S. (1989). Tradisi Lisan Sebagai Sumber Informasi Kebudayaan Dalam Analisa Kebudayaan. Jakarta: Depdikbud

[6]. Fadhilah, A. (2013). Kearifan Lokal dalam Membentuk Daya Pangan Lokal Komunitas Molamahu Pulubala Gorontalo. Jurnal AlTurāś, XIX(1), 23-37. https://doi.org/10.15408/bat.v19i1.3696

[7]. Geertz, C. (1960). The Religion of Java. London: The Free Press of Glencoe

[8]. Hasan, S. (2019). Personal communication.

[9]. Ismail, F. (2012). Prolog dalam Buku Dinamika Perkembangan Sistem Kepercayaan Lokal di Indonesia. Jakarta: Kemenag RI

[10]. Keraf, A. S. (2002). Etika Lingkungan. Jakarta: Kompas

[11]. Koentjaraningrat. (1985). Ritus Peralihan di Indonesia. Jakarta: Balai Pustaka

[12]. Moleong, L. J. (2007). Metodologi Penelitian Kualitatif (Edisi Revisi). Bandung: Remaja Rosda Karya

[13]. Obie, M. (2015). Perampasan Hak Ulayat Pesisir dan Laut Komunitas Suku Bajo (Kasus Pengelolaan Sumber Daya Pesisir dan Laut di Teluk Tomini). Bogor: Disertasi Sekolah Pascasarjana IPB

[14]. Obie, M., Pakaya, M., Mustakimah, \& Syilfi. (2020). Oilm Palm Expansion and Livelihood
Vulnerability on Rural Communities (A Case in Pouwato Regency - Indonesia). Humanities Social Sciences Reviews, 8(1), 01-12. https://doi.org/10.18510/hssr.2020.811

[15]. Odea, T. F. (1996). Sosiologi Agama; Suatu Pengantar, Terjm, Tim Yasogama, Jakarta: Rajawali Press

[16]. Rusli, M. (2016). Persepsi Masyarakat Tentang Makam Raja dan Wali Gorontalo. El Harakah, 18(1), 76-93. http://dx.doi.org/10.18860/el.v18i1.3417

[17]. Sambas, Sy. (2015). Sosiologi Komunikasi. Bandung: Pustaka Setia

[18]. Sugiyono. (2009). Memahami Penelitian Kualitatif. Bandung: Alfabeta

[19]. Surakhmad, W. (1982). Pengantar Penelitian Ilmiah: Dasar, Metode dan Teknik. Bandung: Tarsito.

[20]. Suryani, S. D. (2014). Tayub As A Symbolic Interaction Medium in Sedekah Bumi Ritual in Pati Regency. Harmonia: Journal of Arts Research and Education, 14(2), 97-106. https://doi.org/10.15294/harmonia.v14i2.3291

[21]. Spradley, J. P. (2007). Metode Etnografi, Edisi II. Yogyakarta: Tiara Wacana.

[22]. Turner, J. F. C. (1982). Housing by People: Towards Autonomy in Building Environments. London: Marion Boyars Publishers Ltd.

\section{Cite this article as :}

Momy A. Hunowu, Hatim B. Pakuna, Lahaji, Muhammad Obie, "Mopo'a Huta on Peasant Community: A Ritual for Harmony with Nature in Molamahu Village of Gorontalo Regency - Indonesia", International Journal of Scientific Research in Science and Technology (IJSRST), Online ISSN : 2395-602X, Print ISSN : 2395-6011, Volume 7 Issue 1, pp. 220-228, January-February 2020. Available at doi : https://doi.org/10.32628/IJSRST207143 Journal URL : http://ijsrst.com/IJSRST207143 